\title{
Studies on Experimental Diabetes in the Wellesley Hybrid Mouse*
}

\author{
II. Serum Insulin Levels and Response of Peripheral Tissues**
}

\author{
G. F. Camill, Jr., *** E. E. Jones, V. Lauris, J. Steinke and J. S. Soltdder
}

Departments of Medicine and Pathology, Harvard Medical School and the Peter Bent Brigham Hospital and the Cancer Research Foundation, Children's Hospital, and the Diabetes Foundation, Inc., Boston, Mass.

Summary. A hybrid of C3Hf and I strains of mice (the "Wellesley" mouse) results in an animal with a predisposition to diabetes mellitus. In this study it was found that animals that developed the diabetic syndrome had elevated levels of immunoreactive insulin in their serum, and peripheral tissues that in vitro were less responsive to insulin. Dietary restriction prevented the diabetes from occurring as well as maintaining insulin sensitivity in peripheral tissue.

Etudes du syndrome diabétique des souris hybrides de Wellesley. II. Taux d'insuline sérique et sensibilité à l'insuline des tissus de la périphérie.

Résumé. L'hybride $\mathrm{F}_{1}$ produit par le croisement des souches de souris C3Hf et I (souris de Wellesley) est prédisposé au diabète. Dans cette étude nous avons observé que les animaux devenus diabétiques avaient des taux élevés d'insuline immunoréactive sérique et que leurs tissus périphériques étaient moins sensibles à l'action de l'insuline in vitro. Un régime hypocalorique a pu prévenir l'apparition du diabète et maintenir une sensibilité normale à l'insuline.
Der experimentelle Diabetes der hybriden WellesleyMaus. II. Serum Insulin und Empfindlichleit der peripheren Gewebe.

Zusammenfassung. Die Kreuzung von C3Hf und I Mäusestämmen ergibt ein $\mathrm{F}_{1}$ Hybrid (die "Wellesley" Maus) mit Veranlagung für Diabetes mellitus. Bei der Untersuchung dieser Tiere wurde festgestellt, daß solche, bei denen das diabetische Syndrom sich entwickelt hatte, erhöhte Spiegel von immunreaktivem Insulin im Serum aufwiesen, und daß ihre peripheren Gewebe in vitro weniger empfindlich auf Insulin reagierten. Diätbeschränkung verhinderte das Auftreten von Diabetes und bewahrte die Insulinempfindlichkeit der peripheren Gewebe.

Key-words: Spontaneous Diabetes. Wellesley hybrid mouse, Hybrid mouse diabetes, Genotype: C3Hf $\times I-F l$, Strains of mice : C3Hf and I, Mice: C3Hf and I, Insulin response, Insulin resistance, Nutrition and diabetes, Diet and diabetes, Insulin and diabetes, Insulin in serum, Obesity, Adipose tissue in vitro, Diaphragm in vitro.
During a systematic study of tumour development in inbred strains of mice, it was noted by one of the authors (E. J.) that hybridization of C3Hf and I strains resulted in an animal (the "Wellesley" mouse) that developed striking hyperplastic changes in the islets of Langerhans (JoNEs, 1964). About 50-55\% of the males had intermittent and, some, persistent glycosuria. It was suggested that hyperglycemia first appeared, followed by Beta cell hyperplasia and hyperinsulinemia. This paper reports results of some dietary and metabolic studies in these mice. A more extensive description of the various morphologic ehanges has been published (LJKE et al., 1965).

\section{Materials and methods}

Inbred females of the C3Hf strain were bred with males of the $I$ strain, and the animals under study were 36 male offspring between 2 and 6 months of age. These were divided into 2 populations pairing, when possible, litter mates and animals of similar ages into opposite groups. One group was given Purina Laboratory Chow (St. Louis, Missouri) ad libitum, and animals in the other group were fed for the 4 month period of study

* Supported in part by Grants from the United States Public Health Service AM-09584-01, AM-09748-01, T 1 AM-05077-10, 5 RO1 CA 07726-03, and the John A. Hartford Foundation, Ine.

** Paper I of this series is LIKE et al., 1965.

*** Investigator, Howard Hughes Medical Institute. only that amount of food required to keep their daily weight constant.

Blood samples were obtained each week from the tip of the tail for glucose analysis (Technicon Autoanalyzer, Chauncey, New York). At the end of the study the animals were rapidly decapitated, the blood was collected, allowed to clot, and serum separated for insulin immunoassy (SoELDNER and SLONE, 1965'). The liver was rapidly excised, cooled, weighed, and samples taken for hexokinase, gltucokinase, and glucose-6-phosphatase activities and glycogen determinations (LACRIS and CAHILL, 1966).

Both hemidiaphragms were then excised and incubated in $2 \mathrm{ml}$ Krebs-Ringer bicarbonate buffer containing $1 \mathrm{mg} / \mathrm{ml}{ }^{14} \mathrm{C}$ glucose $(0.5 \mu \mathrm{c} / \mathrm{ml})$ and with or without $500 \mu \mathrm{U} / \mathrm{ml}$ of crystalline pork insulin (Eli Lilly and Co., Dr. Wm. R. Kirtley). The flasks were gassed with $5 \% \mathrm{CO}_{2}: 95 \% \mathrm{O}_{2}$ for 8 minutes, capped, and shaken for 90 minutes at $38^{\circ} \mathrm{C}$. At the end of the incubation, tissues were removed, and ${ }^{14} \mathrm{C}$ in tissue glycogen (PARTamian et al., 1966) and glucose concentration in the medium determined.

Similary, two pieces of epididymal adipose tissue were excised and incubated for 3 hours with glucose-1${ }^{14} \mathrm{C}$ without and with insulin, $500 \mu \mathrm{U} / \mathrm{rnl}$, and oxidation

1 Rat insulin used as standard was a gift from Dr. J. SchLICHTKRULI, Novo Research Institufe, Copenhagen, Denmark. 
of glucose carbon to ${ }^{14} \mathrm{CO}_{2}$ and incorporation into lipid and glycogen were determined by methods previously described (Martin et al., 1958, CaHILL et al., 1959).

\section{Results}

Persistent hyperglycemia developed in 3 animals in group I (fed ad libitum) and several others had mean values that were significantly above the average of group I, and well above the mean value of the animals in group II (restricted diet). These hyperglycemic animals also had markedly elevated levels of serum insulin (Fig. 1); however, there was no correlation between serum insulin levels and pancreatic insulin content. Nor in this series was there any correlation, sur- bolism, as well as a diminished response to added insulin (Table 1). The tissues of the $\mathbf{3}$ animals in group I that developed diabetes failed to show any effect whatsoever of insulin added to their tissues in vitro, in keeping with their markedly elevated levels of immuno-reactive insulin in vivo.

\section{Discussion}

The animals that developed hyperglycemia in this series exhibited a constellation of biochemical abnormalities: increased body weight, elevated liver glycogen, elevated hepatic glucokinase and glucose-6phosphatase activities, elevated levels of serum immunoreactive insulin and apparent insulin ineffec-
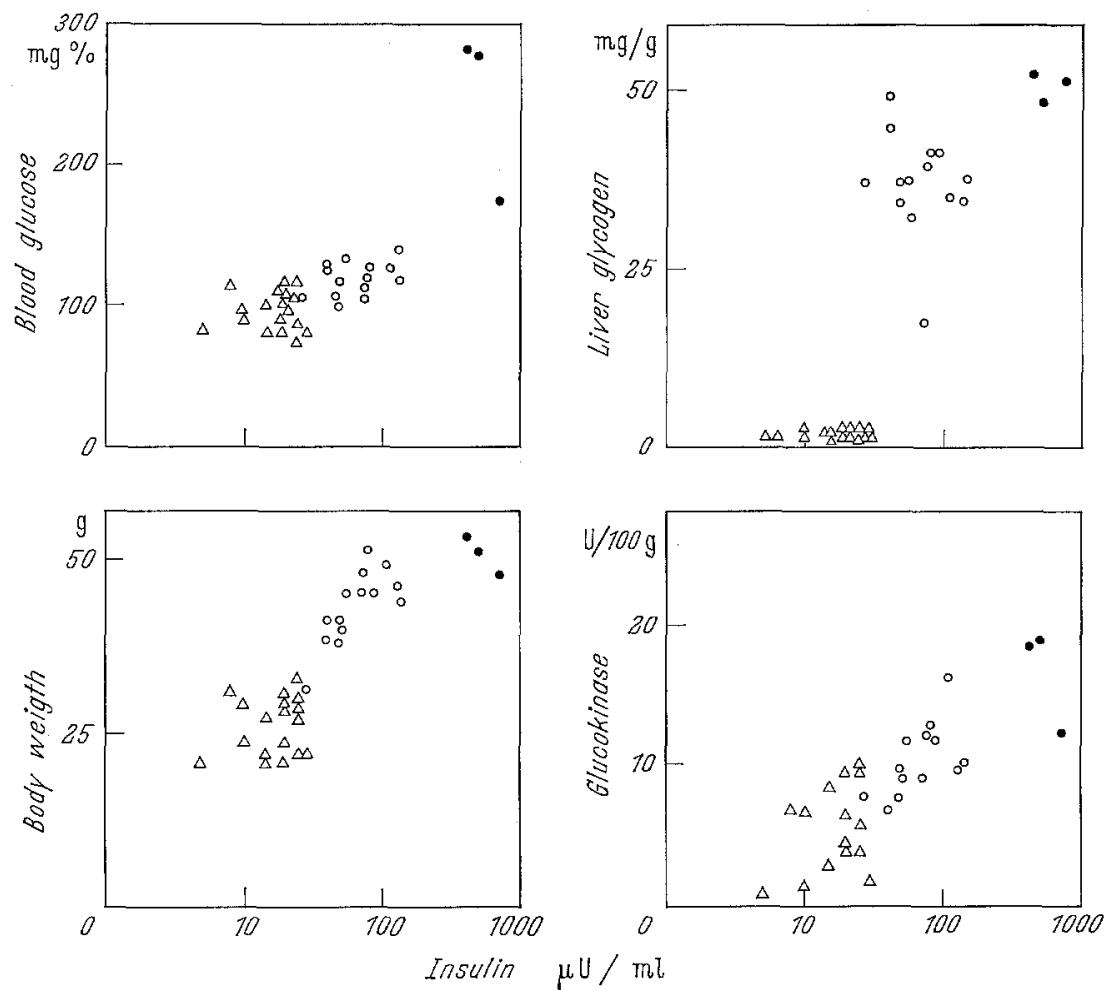

Fig. 1. Plots or insulin levels on the abscissa (logarithmic scale) with levels of blood glucose, liver glycogen, body weight and liver glucokinase activities. Animals fed the restricted diet are presented as triangles, animals fed ad libitum as open and black circles, and the 3 animals fed ad libitum and with diabetio glucose values as black circles

prisingly, between insulin content of the islet tissue and the degree of islet cell abnormality as noted by gross examination. However, there was histologic evidence of Beta-cell degranulation in the 2 animals with hyperglycemia at the time of sacrifice.

Levels of hepatic glucokinase appeared elevated in these diabetic animals (Fig. 1), as did the levels of glucose-6-phosphatase (mean value 66 units, compared with average of 55 units for the ad libitum fed group as a whole).

Incubation of epididymal adipose tissue and hemidiaphragms from the ad libitum fed group demonstrated a markedly decreased basal level of glucose meta- tiveness on their peripheral tissues, as assayed in vitro (this last phenomenon, however, was not statistically significant due to the small number of animals with diabetes that were studied).

Of marked interest is the fact that the animals were hybrids of two highly inbred strains, theoretically making them genetically identical. One must then question the variability in biological response. The animals were all maintained in separate cages and every effort was made to equalize environmental stimuli during the study. Subsequent studies in these and other mice have demonstrated that sporadic diabetes may occur in the commercial laboratory mouse (GLEASON et al., 1967) 
and, again, is associated with the similar constellation of biochemical parameters as noted above, particularly if fed a high calorie diet.

The mice in this study that were fed the restricted diet should not be directly compared with the random. fed animals, since, as occurs in all restricted feedings, their food was devoured rapidly after its offering each morning. Thus, these tissues from the restricted-fed animals reflect a stuff-starve type regimen in addition to caloric restriction; and baseline and insulin sensitivities must be judged accordingly. Nevertheless, none of these animals developed the diabetic syndrome, and their tissues were much more responsive to insulin in vitro. hyperglycemia and decreased peripheral sensitivity of tissues to insulin reflect ineffective insulin activity. Or, more simply, the animals possess a "fed" or "insulinized" liver and a "diabetic" or "fasted" periphery. A similar pattern has been suggested to occur in man with mild diabetes and carbohydrate-induced hyperlipemia (FArquHar et al., 1966). Many more experiments must be performed before the time sequence of the alterations in these animals can be defined.

The relatively low yield of diabetes in the ad libitum fed group in this study was a surprise, since previous studies resulted in a much higher yield in addition to more marked islet tissue abnormalities. The animals in the previous study were raised in different quarters

Table 1

\begin{tabular}{|c|c|c|c|}
\hline & Ad lib & Restricted & $\begin{array}{l}\text { Probability of difference } \\
\text { between ad lib and } \\
\text { restricted feeding }\end{array}$ \\
\hline Number of animals & 18 & 18 & \\
\hline Body wt (g) & $44.2 \pm 1.3$ & $26.3 \pm 1.0$ & $<0.001$ \\
\hline Blood glucose $(\mathrm{mg} / 100 \mathrm{ml})$ & $138 \pm 13$ & $\mathbf{9 8} \pm \mathbf{3}$ & $<0.01$ \\
\hline $\begin{array}{l}\text { Serum immunoreactive } \\
\text { insulin }(\mu \mathrm{U} / \mathrm{ml})\end{array}$ & $155 \pm 48$ & $19 \pm 2$ & $<0.01$ \\
\hline $\begin{array}{l}\text { Pancreatic insulin } \\
\text { content (U/100 g body wt) }\end{array}$ & $5.0 \pm 0.6$ & $4.1 \pm 0.6$ & N.S. \\
\hline $\begin{array}{l}\text { Liver-glycogen }(\mathrm{mg} / \mathrm{g}) \\
\text { hexokinase } \\
\text { glucokinase }^{1} \\
\text { glucose- } 6 \text {-phosphatase }^{1}\end{array}$ & $\begin{array}{l}41 \pm 2 \\
0.60 \pm 0.07 \\
11.4 \pm 0.9 \\
55 \pm 2\end{array}$ & $\begin{array}{l}0.8 \pm 0.1 \\
0.57 \pm 0.10 \\
5.5 \pm 0.8 \\
43 \pm 1\end{array}$ & $\begin{array}{l}<0.001 \\
\text { N.S. } \\
<0.001 \\
<0.001\end{array}$ \\
\hline $\begin{array}{l}\text { Adipose tissue incubation } \\
\mathrm{Cpm} \text { in } \mathrm{CO}_{2} / \mathrm{mg} / 3 \text { hours } \\
\mathrm{Cpm} \text { in lipid } \\
\mathrm{Cpm} \text { in glycogen } \\
\text { Insulin effect in } \mathrm{CO}_{2}{ }^{2} \\
\text { Insulin effect in lipid } \\
\text { Insulin effect in glycogen }{ }^{2}\end{array}$ & $\begin{array}{l}74 \pm 16 \\
54 \pm 16 \\
0.26 \pm 0.01 \\
2.1 \pm 0.3(<0.001) \\
3.0 \pm 0.5(<0.001) \\
3.8 \pm 0.9(<0.01)\end{array}$ & $\begin{array}{l}1001 \pm 320 \\
615 \pm 62 \\
1.13 \pm 0.30 \\
6.7 \pm 2.1(0.05) \\
9.4 \pm 2.2(<0.001) \\
1.4 \pm 0.2(<0.05)\end{array}$ & $\begin{array}{l}<0.001 \\
<0.001 \\
<0.01 \\
<0.05 \\
<0.01 \\
<0.01\end{array}$ \\
\hline $\begin{array}{l}\text { Diaphragm incubation } \\
\text { Glucose uptake mg/g/1 hr } \\
\text { Glucose insulin effect } \\
\text { Cpm in glycogen. } \\
\text { Cpm in insulin effect }\end{array}$ & $\begin{array}{l}3.39 \pm 0.28 \\
1.17 \pm 0.11(\mathrm{NS}) \\
140000 \pm 4000 \\
1.07 \pm 0.02(<0.01)\end{array}$ & $\begin{array}{l}4.55 \pm 0.49 \\
1.65 \pm 0.33(<0.05) \\
110000 \pm 7000 \\
1.44 \pm 0.16(<0.01)\end{array}$ & $\begin{array}{l}<0.05 \\
\text { N.S. } \\
<0.001 \\
<0.01\end{array}$ \\
\hline
\end{tabular}

1 Activities as Units/100 g body wt (LAURIS and CAHILL, 1966).

2 Insulin effects = insulin stimulated tissues/non-insulin stimulated tissue probability of significance of effect.

In the common laboratory rat, starvation is associated with a decrease in glucokinase activity, which is returned to normal by food administration as long as insulin is available; in alloxan diabetes the enzyme is usually not detectable (LAuRIS and CAHILL, 1966; DiPietro et al., 1962; DiPietro and Weinhouse, 1963). These mice, as also noted in the dietary-induced diabetes in the sand rat (MukI et a1., 1966), paradoxically possess normal or increased levels of the enzyme, as well as high levels of liver glycogen. Thus, glucose and/or insulin, if these are the inducing agents for hepatic glucokinase, as has been suggested by a number of investigators, are elevated in this type of diabetes and yet are effective in increasing the activity of hepatic glucokinase. In other words, the liver enzyme pattern reflects adequate insulin activity, whereas the and were fed Old Guilford Breeder Ration (Guilford, Connecticut) which contains $11 \%$ fat in contrast to $3 \%$ fat in the Purina Lab ration. This difference in food and incidence of diabetes and islet abnormalities instigated a second series of experiments, which are reported in an accompanying paper (GLeason et al., 1967).

\section{References}

Cahill, G.F., Jr., B. Leboevt and A. E. Renold : Studies on rat adipose tissue in vitro. III. Synthesis of glycogen and glyceride-glycerol. J. biol. Chem. 234, 2540-2543 (1959).

DeFronzo, R., E. MıkI and J. Steinke: Diabetic syndrome in sand rats. III. Observations on adipose tissue and liver in the non-diabetic stage. Diabetologia, 3, 140-142 (1967). 
DiPietro, D.C., C. Sharma and S. Weinhouse: Studies on glucose phosphorylation in rat liver. Biochem. J. 1, 452-62 (1962).

- and S. Wernhouse: Hepatic glucokinase in the fed, fasted and alloxan-diabetic rat. J. biol. Chem. 235, $2592-5(1963)$.

FarquHar, J.W., A. Frank, R.C. Gross and G.M. ReaVEN: Glucose, insulin and triglyceride responses to high and low carbohydrate diets in man. J. clin. Invest. 45, 1648-1656 (1966)

Gleason, R., V. Lauris and J.S. Soemdner : Studies on experimental diabetes in the Wellesley Hybrid Mouse. III. Effects of diet and similar changes in a commercial strain (Swiss-Hauschka). Diabetologia, 3, 175-178 (1967).

JoNES, E.: Spontaneous hyperplasia of the pancreatic islets associated with glucosuria in hybrid mice. In The Structure and metabolism of the pancreatic islets, Brolin, S.E., B. Hellman and H. Knutson eds. Oxford, Pergamon Press, pp. 189-191, 1964.

LaURIS, V., and G.F. CAHILI, Jr.: Hepatic glucose phosphotransferases, variations among species. Diabetes 15, 475-479 (1966).

Like, A.A., J. Streinke, E.E. Jonks and G.F. CAHILL,
Jr.: Pancreatic studies in mice with spontaneous diabetes mellitus. Amer. J. Path. 46, 621-644 (1965).

Martin, D.B., A.E. Renold and Y.M. Dagenats: An assay of insulin-like activity using rat adipose tissue. Lancet 1958 II, 76-77

Miki, E., A.A. LIKE, J.A. Soteddner, J. Steinke and G.F. CAHIII, Jr.: Acute ketotic-type diabetic syndrome in sand rats (Psammomys obesus) with special reference to the pancreas. Metabolism 15, 149-160 (1966).

Partamtan, J., E. Rasto and G.F. Cahrte, Jr.: Studies using the intraperitoneal assay on the state of insulin in rat serum. Metabolism 15, 70-75 (1965).

SoELDNER, J.A., and D. StonE: Critical variables in the radioimmunoassay of serum insulin using the double antibody technic. Diabetes 14, 771-9 (1965).

STEINKe, J., and S. G. DRIscort: The extractable insulin content of pancreas from fetuses and infants of diabetic and control mothers. Diabetes 14, 573-578 (1965).

George F. CahtLt, Jr., M.D. Department of Medicine Harvard Medical School 170 Pilgrim Road Boston, Mass. 02215, U.S.A. 